\title{
Early Sixteenth Century Caddo Population Distributions
}

Timothy K. Perttula

Heritage Research Center, Stephen F. Austin State University

Follow this and additional works at: https://scholarworks.sfasu.edu/ita

Part of the American Material Culture Commons, Archaeological Anthropology Commons, Environmental Studies Commons, Other American Studies Commons, Other Arts and Humanities Commons, Other History of Art, Architecture, and Archaeology Commons, and the United States History Commons

Tell us how this article helped you.

This Article is brought to you for free and open access by the Center for Regional Heritage Research at SFA ScholarWorks. It has been accepted for inclusion in Index of Texas Archaeology: Open Access Gray Literature from the Lone Star State by an authorized editor of SFA ScholarWorks. For more information, please contact cdsscholarworks@sfasu.edu. 


\section{Early Sixteenth Century Caddo Population Distributions}

Creative Commons License

(c) $)$ (i) @

This work is licensed under a Creative Commons Attribution-NonCommercial 4.0 International License 


\title{
Early Sixteenth Century Caddo Population Distributions
}

\author{
Timothy K. Perttula
}

Milner's (2015:Figure 2.1) summary of the distribution of Native American population aggregates in eastern North America in the early sixteenth century depicts much of the southern Caddo area (of southwestern Arkansas, northwestern Louisiana, southeastern Oklahoma, and East Texas) as being sparsely settled or uninhabited in the early sixteenth century. Rather, as attested to by many years of archaeological investigations of a variety of Caddo sites across the southern Caddo area, as well as the 1542 accounts of the de Soto-Moscoso entrada, the distribution and density of Caddo farming groups and communities reached its full and peak extent at around this time.

The distribution of native American populations in eastern North America at the time of initial European contacts in the early to mid- $16^{\text {th }}$ century (see Jones 2014 :Figure 2) has been important to establish in order to assess the place of Native American communities and groups across the landscape, the short- and long-term effects of European contact, and the consequences of population change and decline following the introduction, timing, and spread of Old World diseases after European contact. The research by George R. Milner (2015; see also Milner and Chaplin 2010) on depopulation, movement, and warfare among Eastern North American Native American groups in the early sixteenth century has laid the foundation for a better understanding of their spatial distribution and their mean and absolute population sizes (Milner and Chaplin 2010:Figures 4-5 and Table 2). In turn, these findings have provided insights into the effects of European contact from the early $16^{\text {th }}$ century on across eastern North America, and Milner (2015:66) has concluded that:

much of the mid-continent was sparsely settled, surviving groups had spaced themselves as far apart as possible... When new diseases were introduced, isolation by distance likely impeded the spread of pathogens transmitted through direct person-to-person contact.

As part of Milner's research, he has compiled a map showing the distribution of "archaeologically identifiable early sixteenth-century population aggregates" (Milner 2015:54 and Figure 2.1) that extends from the Atlantic Ocean on the east to the Caddo populations at the far western reaches of eastern North America. Figure 1 provides the locations of the population aggregates identified by Milner (2015:Figure 2.1) in the southern Caddo area (Perttula 2012:Figure 1-2). According to Milner (2015:54), the unshaded areas on the map represent "tracts of unoccupied land," or land that was sparsely settled at that time by Native American groups, including Caddo groups and communities.

However, more than 100 years of archaeological investigations in the southern Caddo area indicate that there is abundant evidence of Caddo settlements - ranging from small farmsteads, small hamlets, to larger villages, and multiple mound community centers - in some density in this area in the early sixteenth century (Girard et al. 2014:68, 71-75 and Figure 3.1). Milner's (2015:Figure 2.1) contention that large swathes of East Texas (as well as other parts of the southern Caddo area in Louisiana and Arkansas) were unoccupied in the early $16^{\text {th }}$ century, or are "places that are poorly known or those occupied by people who moved often," widely misses the mark. Although rigorous regional settlement demographic studies (see Drennan et al. 2015) have not been done for any temporal period of the Caddo archaeological record, the study of the settlements of Caddo peoples between ca. A.D. 1400-1680 indicates that Caddo groups of varying sizes, complexity, and local history were widely distributed across both major 


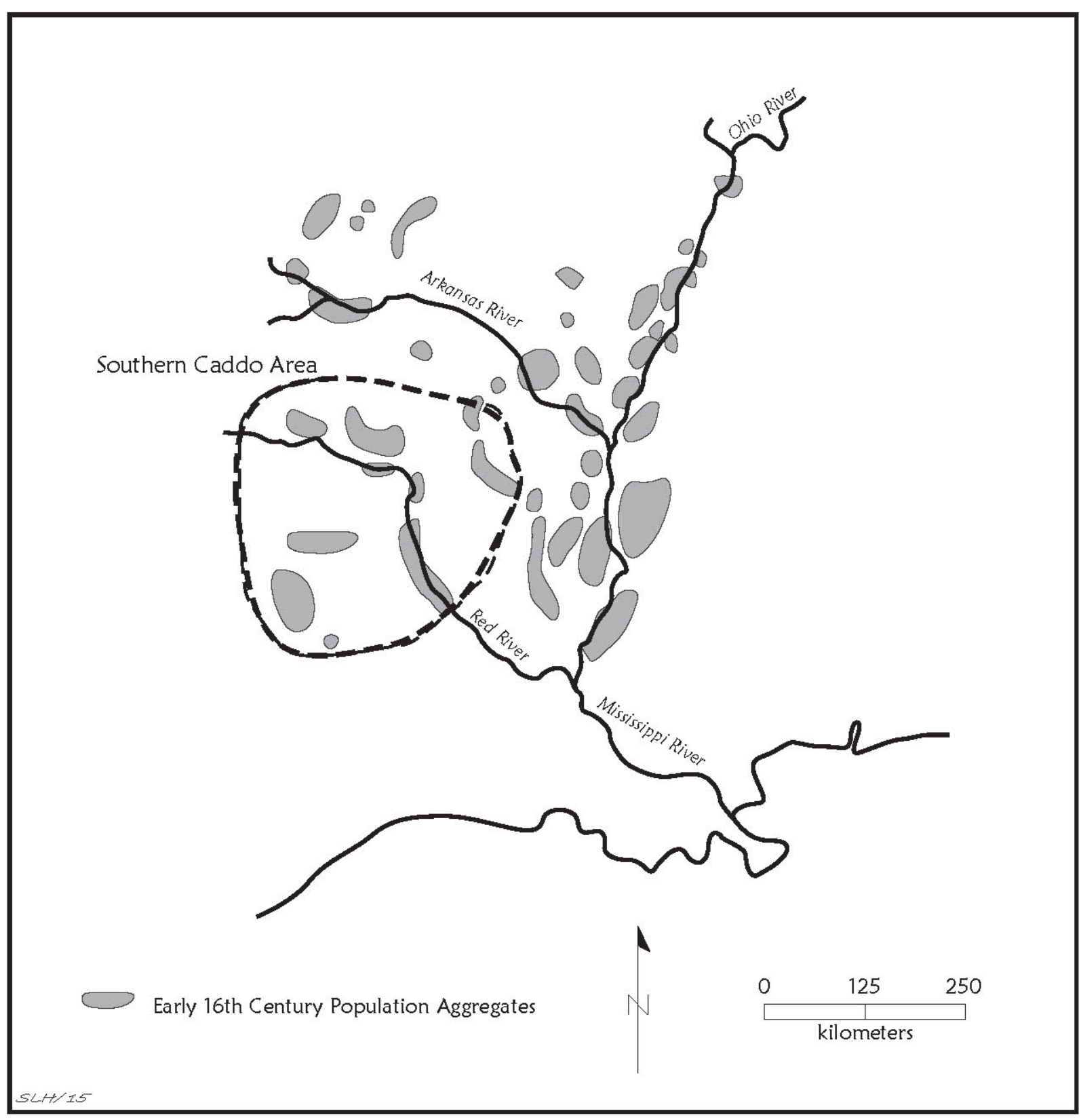

Figure 1. Early sixteenth century population aggregates in the western part of eastern North America. This figure is redrawn from Milner (2015:Figure 2.1) to focus on the southern Caddo area and immediately adjacent regions. Figure prepared by Sandra Hannum.

and minor streams in virtually all parts of the southern Caddo area, including within contemporaneous phases in the region. If anything, by all measures, the period between ca. A.D. 1400 (the onset of the Late Caddo period, ca. A.D. $1400-1680$ ), the mid- $16^{\text {th }}$ century, and then on to the latter part of the $17^{\text {th }}$ century, were as Girard et al. (2014) has indicated, likely periods of peak Caddo population densities and settlement extent across the region (Figure 2). The largest Late Caddo period mound in East Texas outside of the Red River, the Pine Tree Mound site (41HS15), was continuously occupied through the $16^{\text {th }}$ and much of the $17^{\text {th }}$ century A.D. (Fields 2008). The distribution of Caddo settlements, communities, and phases through this period also suggests that the adverse effects of European epidemic diseases, including depopulation, did not occur until after A.D. 1680. 


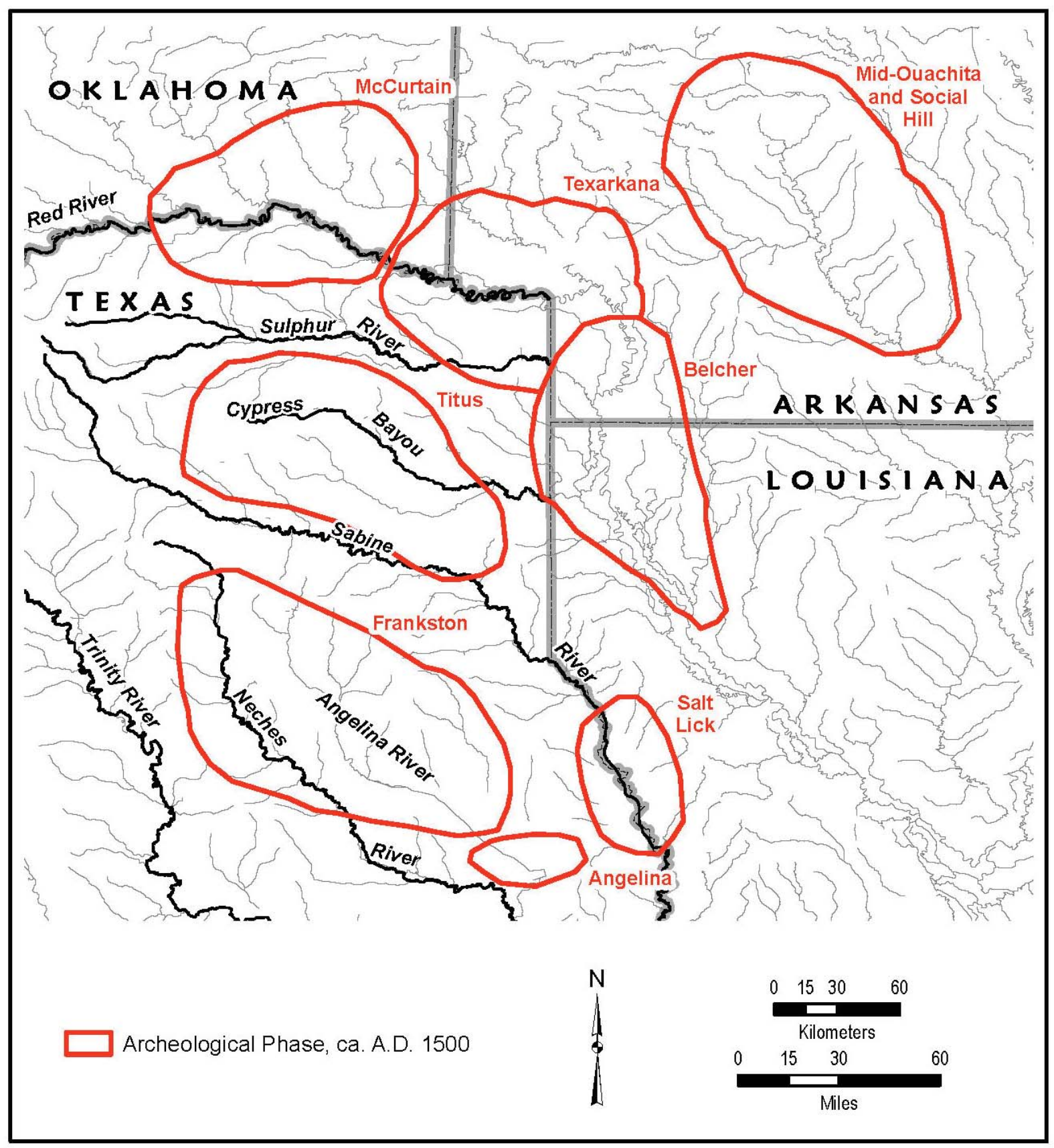

Figure 2. Distribution of defined phases in the southern Caddo area at ca. A.D. 1500. Figure prepared by Sandra Hannum.

When the de Soto-Moscoso entrada encountered Caddo groups along the Ouachita River in what is now southwestern Arkansas at the province of Chaguate in 1542 (Figure 3), they noted a well peopled province (Hudson 1993, 1997:329); Naguatex on the Red River was similarly described as a fertile and well-populated land. While there may have been buffers between Caddo provinces, particularly south of the Sabine River, there were well-populated Caddo communities along almost all the route taken by the entrada. The entrada accounts do not identify large areas that were uninhabited or sparsely settled by Caddo groups at that time (see Schambach 1989, 1993; Bruseth and Kenmotsu 1991, 1993; Early 1993; Hoffman 1993; Kenmotsu et al. 1993; Young and Hoffman 1993). 


\section{Moscoso Route}

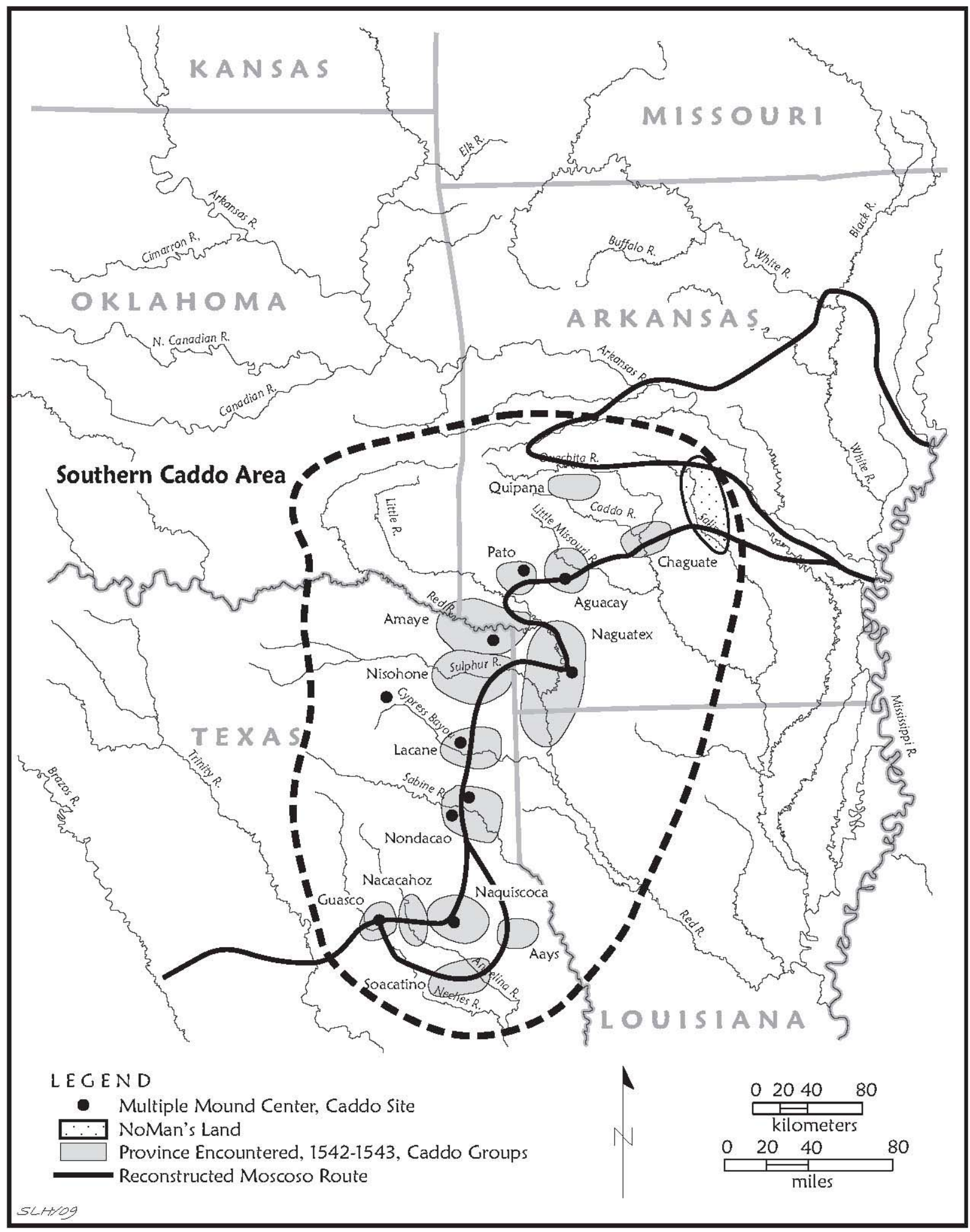

Figure 3. Map of the postulated de Soto-Moscoso entrada across the southern Caddo area and selected Caddo provinces in Southwest Arkansas and East Texas in 1542. Figure prepared by Sandra Hannum. 


\section{Conclusions}

The characterization by Milner (2015:Figure 2.1) of much of the southern Caddo area as being sparsely settled or uninhabited in the early sixteenth century is not an accurate one. Rather, the distribution and density of Caddo farming groups and communities reached its full and peak extent at around this time, as attested to by archaeological investigations of a variety of Caddo sites across the southern Caddo area as well as the 1542 accounts of the de Soto-Moscoso entrada.

\section{References Cited}

Bruseth, J. E. and N. A. Kenmotsu

1991 Soldiers of Misfortune: The de Soto Expedition Through Texas. Heritage 9:12-18. Texas Historical Foundation, Austin.

1993 From Naguatex to the River Daycao: The Route of the Hernando de Soto Expedition Through Texas. North American Archaeologist 14(2):99-125.

Drennan, R. D., C. A. Berrey, and C. E. Peterson

2015 Regional Settlement Demography in Archaeology. Eliot Werner Publications, Inc., Clinton Corners, New York.

Early, A. M.

1993 Finding the Middle Passage: The Spanish Journey from the Swamplands to Caddo Country. In The Hernando de Soto Expedition West of the Mississippi, 1541-1543, edited by G. A. Young and M. P. Hoffman, pp. 68-77. University of Arkansas Press, Fayetteville.

Fields, R. C.

2008 The Pine Tree Mound Site and the Entrada of the Hernando De Soto Expedition of 1542. Journal of Northeast Texas Archaeology 28:1-8.

Girard, J. S., T. K. Perttula, and M. B. Trubitt

2014 Caddo Connections: Cultural Interactions within and beyond the Caddo World. Rowman \& Littlefield, Lanham, Maryland.

Hoffman, M. P.

1993 Identification of Ethnic Groups Contacted by the de Soto Expedition in Arkansas. In The Expedition of Hernando de Soto West of the Mississippi, 1541-1543: Proceedings of the De Soto Symposia, 1988 and 1990, edited by G. A. Young and M. P. Hoffman, pp. 132-142. University of Arkansas Press, Fayetteville.

Hudson, C. M.

1993 Reconstructing the de Soto Expedition Route West of the Mississippi River: Summary and Contents. In The Expedition of Hernando de Soto West of the Mississippi, 1541-1543: Proceedings of the De Soto Symposia, 1988 and 1990, edited by G. A Young and M. P. Hoffman, pp. 143-154. University of Arkansas Press, Fayetteville.

1997 Knights of Spain, Warriors of the Sun. University of Georgia Press, Athens.

Jones, E. E.

2014 Spatiotemporal Analysis of Old World Diseases in North America, A.D. 1519-1807. American Antiquity 79(3):487-506.

Kenmotsu, N. A., J. E. Bruseth, and J. E. Corbin

1993 Moscoso and the Route in Texas: A Reconstruction. In The Hernando de Soto Expedition West of the Mississippi, 1541-1543: Proceedings of the De Soto Symposia, 1988 and 1990, edited by G. A. Young and M. P. Hoffman, pp. 106-131. University of Arkansas Press, Fayetteville. 
Milner, G. R.

2015 Population Decline and Culture Change in the American Midcontinent: Bridging the Prehistoric and Historic Divide. In Beyond Germs: Native Depopulation in North America, edited by C. M. Cameron, P. Kelton, and A. C. Swedlund, pp. 50-73. The University of Arizona Press, Tucson.

Milner, G. R. and G. Chaplin

2010 Eastern North American Population at ca. A.D. 1500. American Antiquity 75(4):707-726.

Perttula, T. K.

2012 The Archaeology of the Caddo in Southwest Arkansas, Northwest Louisiana, Eastern Oklahoma, and East Texas: An Introduction to the Volume. In The Archaeology of the Caddo, edited by T. K. Perttula and C. P. Walker, pp. 1-25. University of Nebraska Press, Lincoln.

Schambach, F. F.

1989 The End of the Trail: The Route of Hernando De Soto's Army Through Southwest Arkansas and East Texas. The Arkansas Archeologist 27/28:9-33.

1993 The End of the Trail: Reconstruction of the Route of Hernando de Soto's Army through Southwest Arkansas and East Texas. In The Expedition of Hernando de Soto West of the Mississippi, 1541-1543. Proceedings of the de Soto Symposia, 1988 and 1990, edited by G. A. Young and M. P. Hoffman, pp. 78-105. University of Arkansas Press, Fayetteville.

Young, G. A. and M. P. Hoffman (editors)

1993 The Expedition of Hernando de Soto West of the Mississippi, 1541-1543: Proceedings of the DeSoto Symposia, 1988 and 1990. University of Arkansas Press, Fayetteville. 